\title{
MODEL KOMUNIKASI KYAI DENGAN SANTRI DI PESANTREN
}

\author{
Mansur Hidayat \\ Program Pascasarjana Jurusan Interdisciplinary Islamic Studies, Konsentrasi Kajian \\ Komunikasi dan Masyarakat Islam UIN Sunan Kalijaga, Jl. Marsda Adisucipto \\ Yogyakarta 55281. No.Hp. 085740324331, \\ Email: mansurhidayat.id@gmail.com
}

\begin{abstract}
The existence of Islamic boarding school (pesantren) can't be separated from the figure of a clerics (kyai) and the communication between clerics and students (santri). Using qualitative research approach, this study aims to to prepare, understand and analyze communication models between clerics and students in Pesantren Raudhatul Qur'an An-Nasimiyyah. Communication Model between clerics and students in Islamic boarding school is influenced by the concept of Morals, status and charisma of clerics. Moral education is a way to establish communication that facilitates management of transfer of knowledge to students. Status and charisma of clerics are enhancer factor communicator legitimacy in the context of Islamic boarding school. The research concludes that the construction of communications models of clerics and students was formed by highintensity interactions between clerics and students.
\end{abstract}

Key Words: Communication Patterns, Kyai, Islamic Boarding School, Santri.

\begin{abstract}
Abstrak
Keberadaan pesantren tak bisa dipisahkan dari sosok kyai dan komunikasi yang dilakukan terhadap santri. Menggunakan metodologi kualitatif, penelitian ini ingin menyusun, memahami, dan menganalisis model komunikasi kyai dengan santri di Pesantren Raudhatul Qur'an An-Nasimiyyah. Model komunikasi Kyai dengan Santri di Pesantren dipengaruhi oleh konsep Akhlak, Status Kyai dan Kharisma Kyai. Pendidikan akhlak merupakan cara membentuk komunikasi dalam pesantren yang memudahkan manajemen transfer ilmu ke santri. Status dan kharisma Kyai merupakan faktor penambah legitimasi komunikator dalam konteks pondok pesantren. Penelitian menyimpulkan bahwa konstruksi model komunikasi kyai dan santri terbentuk dari intensitas interaksi yang tinggi antara kyai dengan santri.
\end{abstract}

Kata Kunci : Pola Komunikasi, Kyai, Pesantren, Santri.

\section{Pendahuluan}

Mengutip dari Paul Latzlawick "People cannot not communicate" (manusia tidak bisa tidak berkomunikasi), dengan kata lain komunikasi adalah salah satu kebutuhan primer manusia (Mulyana, 2004). Jadi dengan kata lain bagaimana kualitas berpikir manusia dapat dilihat dari kualitas komunikasi yang dijalankan. Manusia sebagai individu dalam berkomunikasi dipengaruhi dalam beberapa hal yang dapat dibedakan lagi menjadi dua faktor utama, personal dan situasional. Faktor personal terdiri dari faktor biologis dan faktor sosiopsikologis.
Menurut faktor situasional perilaku manusia dipengaruhi oleh lingkungan yang berupa faktor ekologis, misalnya kondisi alam atau iklim, faktor rancangan dan arsitektural, misalnya penataan ruang, faktor temporal, misalnya keadaan emosi, suasana perilaku, misalnya cara berpakaian dan cara berbicara, teknologi, faktor sosial, mencakup sistem peran, struktur sosial dan karakteristik sosial individu, lingkungan psikososial yaitu persepsi seseorang terhadap lingkungannya, stimulasi yang mendorong dan memperteguh perilaku (Fuad dkk, 2013). 
Menurut Fiske (2012:1) komunikasi diartikan sebagai salah satu aktivitas manusia yang dikenali oleh semua orang namun sangat sedikit yang dapat mendefinisikannya secara memuaskan. Komunikasi memiliki definisi yang tidak terhingga seperti saling berbicara satu dengan yang lain, televisi, penyebaran informasi, gaya rambut kita, karya sastra, dan masih banyak lagi. Selanjutnya Uchayana (2002:11) mendefinisikan komunikasi sebagai proses penyampaian pikiran, atau perasaan oleh seseorang (komunikator) kepada orang lain (komunikan). Pikiran dapat berupa gagasan, informasi, opini, dan lain-lain yang muncul dari benaknya. Perasaan dapat berupa keyakinan, kepastian, keraguan, kekhawatiran, kemarahan, keberanian, kegairahan, dan sebagainya yang timbul dari lubuk hati.

Jadi, lingkup komunikasi menyangkut persoalan-persoalan yang ada kaitannya dengan subtansi interaksi sosial orangorang dalam masyarakat, termasuk konten interaksi (komunikasi) yang dilakukan secara langsung maupun dengan menggunakan media komunikasi (Burhan, 2014:31).

Sedangkan dalam perkembangannya, ilmu komunikasi terbagi menjadi dua perspektif utama. Pertama perspektif proses yang melihat komunikasi sebagai transmisi pesan. Dalam perspektif ini mereka tertarik dengan bagaimana pengirim dan penerima mengkonstruksi pesan dan menerjemahkannya, serta bagaimana transmitter menggunakan saluran dan media komunikasi. Perspektif kedua melihat komunikasi sebagai produksi dan pertukaran makna. Hal ini berkenaan dengan bagaimana pesan berinteraksi dengan orang-orang dalam menghasilkan makna (Fuad dkk, 2013:198).

Perubahan yang terjadi khususnya adalah kondisi lingkungan sekitar pesantren yang kondusif, salah satu para- meternya adalah santri pesantren tersebut yang mayoritas mahasiswa ternyata memiliki kegemaran mendengarkan lagulagu bernuansa islami dan senang dalam bermain rebana, bahkan musik yang mereka simpan dalam smartphone mereka salah satunya adalah musik-musik islami dan musik rebana. Musik rebana sendiri adalah musik islami yang berisikan puji-pujian kepada Allah SWT, maupun Nabi Muhammad SAW, hal ini sangat kontras dengan kondisi mahasiswa pada umumnya dimana mereka cenderung menggemari musik yang sedang populer di masyarakat saat ini. Bagi peneliti hal ini merupakan kondisi yang menarik dimana lingkungan pondok berhasil membentuk budaya mereka sendiri (Fuad dkk, 2013:200).

Definisi Kyai dalam Kamus Besar Bahasa Indonesia (2014) adalah sebutan bagi alim ulama' (orang yang cerdik dan pandai dalam agama Islam). Sedangkan dalam Ensiklopedi Islam Indonesia (1992:562) disebutkan bahwa kyai di kalangan masyarakat tradisional Jawa, merupakan tokoh keagamaan kharismatik yang bisa dibandingkan dengan ajengan di masyarakat Jawa Barat, syekh di masyarakat Minangkabau Sumatera Barat. Untuk penyebutan istilah kyai di Indonesia memang berbeda-beda, tetapi substansinya memiliki peran dan tugas yang sama. Untuk persoalan ini, Ali Maschan Moesa (Syamsul, 2010:280) berkata; "ulama juga mempunyai sebutan yang berbeda di setiap daerah, seperti kyai (Jawa), ajengan (Sunda), tengku (Aceh), syekh (Tapanuli), buya (Minangkabau), tuan guru (Nusa Tenggara, Kalimantan Selatan, Kalimantan Timur dan Kalimantan Tengah)". Selain itu, terdapat sebutan 'kyai', yang merupakan gelar kehormatan bagi para ulama pada umumnya. Oleh karena itu, sering dijumpai di pedesaan Jawa panggilan 'Ki Ageng' atau 'Ki Ageng/Ki Gede', juga 'Ki Haji' (Isma'il, 1997: 63). 
Demikianlah gelar bagi ulama yang dijumpai di berbagai tempat di wilayah Indonesia, khususnya Jawa. Bagaimanakah gelar kyai tersebut diperoleh dan syarat-syarat apa yang harus dimiliki untuk bisa disebut 'kyai'? Sebenarnya gelar kyai tersebut adalah sebuah gelar yang langsung diberikan oleh masyarakat kepada seseorang yang dianggap memiliki kualitas dan kapabilitas sebagai seorang kyai.

Dalam masyarakat daerah pedesaan di Jawa, ada kelompok komunitas muslim yang disebut santri. Santri adalah mereka yang dengan taat melaksanakan perintah agamanya, yaitu Islam (Iva, 2011:32). Sedangkan asal-usul perkataan santri menurut Rizki (2010:34) setidaknya ada 2 pendapat yang dapat dijadikan rujukan. Pertama santri berasal dari kata "Santri" dari bahasa sansekerta yang artinya melek huruf. Kedua, kata santri yang berasal dari bahasa Jawa "Cantrik" yang berarti seseorang yang mengikuti seorang guru kemanapun pergi atau menetap dengan tujuan dapat belajar suatu keilmuwan kepadanya.

Pengertian ini senada dengan pengertian santri secara umum, yakni orang yang belajar agama Islam dan mendalami agama Islam di sebuah pesantrian (pesantren) yang menjadi tempat belajar bagi para santri. Jika dirunut dengan tradisi pesantren, terdapat dua kelompok santri, yakni:

Santri mukim yakni murid-murid yang berasal dari daerah jauh dan menetap di pesantren. Santri yang sudah lama mukim di pesantren biasanya menjadi kelompok tersendiri dan sudah memikul tanggung jawab mengurusi kepentingan pesantren sehari-hari, sepeti halnya mengajar santri-santri muda tentang kitab-kitab tingkatan rendah dan menengah.

Santri kalong adalah murid-murid yang berasal dari desa sekelilingnya, yang biasanya mereka tidak tinggal di pesantren kecuali kalau waktu-waktu belajar (sekolah dan mengaji) saja, mereka bolak-balik (nglaju) dari rumah.

Pesantren berasal dari kata pe-santrian yang berarti tempat tinggal santri atau yang dikenal sebagai murid. Pondok berasal dari kata funduuq dari bahasa arab yang berarti penginapan atau asrama. Di dalam pesantren/pondok pesantren kebanyakan dipimpin oleh seorang kyai dan dibantu oleh murid-murid yang telah di tunjuk untuk mengelola pesantren serta mengelola organisasi atau lembaga yang berada dalam pesantren tersebut. Pesantren merupakan institusi pendidikan tertua yang ada di Indonesia yang telah menjadi produk budaya Indonesia dan mengadopsi sistem pendidikan keagamaan yang berkembang sejak awal kedatangan Islam di Nusantara. Pesantren tumbuh dan berkembang melayani berbagai kebutuhan masyarakat, sebagai warisan budaya umat Islam Indonesia. Pesantren merupakan penguhubung antara masyarakat pelosok pedesaan yang belum pernah tersentuh pendidikan modern ketika masyarakat membutuhkan pendidikan (Alim, 2010).

Karel A. Steenbrink dalam bukunya Pesantren Madrasah Sekolah (Syamsul, 2010:280) berkata: Dalam masyarakat tradisional, seorang dapat menjadi kyai atau disebut kyai karena ia diterima masyarakat sebagai kyai, karena orang yang datang meminta nasehat kepadanya, atau mengirimkan anaknya supaya belajar kepada kyai. Memang, untuk menjadi kyai tidak ada kriteria formal seperti persyaratan studi, ijazah dan sebagainya. Akan tetapi ada beberapa syarat non-formal yang harus dipenuhi oleh seorang kyai, sebagaimana syarat non-formal untuk menentukan seseorang menjadi kyai besar dan kecil. Seorang yang berhak menyandang gelar kyai, 
seperti dalam penjelasannya Ronald Alan Lukens-Bull, paling tidak harus memiliki empat komponen, yakni: pengetahuan, kekuatan spritual, keturunan (spritual maupun biologis), dan moralitas. Senada dengan ini, Manfred Ziemek menyebutkan bahwa seorang dapat disebut kyai apabila memenuhi beberapa kriteria, yakni: pertama, berasal dari suatu keluarga kyai di lingkungannya agar dapat menggunakan kesetiaan kerabat dan masyarakatnya. Kedua, sosialisasi dan proses pendidikanya dalam sesuatu pesantren terpandang yang dilengkapi dengan pengalaman dan latar belakang kepemimpinan yang telah ditanamkan. Ketiga, adanya kesiapan pribadi yang tinggi untuk bertugas, yakni kemauan untuk mengabdikan kehidupan pribadinya demi tugasnya di pesantren. Keempat, sebagai pemimpin agama dan masyarakat untuk bekerja secara suka rela guna membangun dan membiayai pesantren. Kelima, mampu mengumpulkan dana dan bantuan tanah wakaf dari warga ekonomi menengah ke atas. Persyaratan lain yang diberikan H. Aboe Bakar Aceh untuk seorang kyai dan sekaligus bisa menunjukkan kebesaranya yakni: 1. Pengetahuanya, 2. Kesalehanya, 3. Keturunannya, dan 4. Jumlah muridnya.

Selanjutnya, Kyai merupakan figur sentral dalam dunia pesantren dan juga faktor determinan terhadap maju dan mundurnya sebuah pondok pesantren termasuk pendidikan dan sistem kurikulumnya bahkan ada pesantren yang tidak menerapkan sistem kurikulum, merupakan hak preogratif kyai (Sri, 2014:631). Dhofier menyebut kyai adalah sebagai elemen yang paling esensial dari pesantren yang seringkali disebut sebagai pendiri pesantren. Dalam penelitiannya, asal-usul penyebutan kyai dalam bahasa jawa digunakan dalam tiga jenis gelar yang berbeda yaitu;
(1) Sebagai gelar kehormatan untuk barang-barang yang antik dan berharga seperti penyebutan 'Kyai Garuda Kencana' bagi kereta emas di Keraton Yogyakarta, (2) Gelar kehormatan bagi orang tua pada umumnya, (3) Gelar yang diberikan oleh masyarakat kepada seorang ahli agama atau menjadi pimpinan pesantren dan mengajar kitabkitab Islam klasik kepada santrinya. Penyebutan gelar yang ketigalah yang digunakan dalam penelitian ini untuk menyebut seorang kyai, yaitu suatu gelar yang diberikan kepada seseorang yang menjadi pendiri dan pemimpin pesantren.

Selanjutnya pendidikan model pesantren (Syamsul, 2010:273-274) memiliki beberapa karakteristik unik bila dibandingkan dengan sistem pendidikan lainya. Karakteristik itulah yang banyak berpengaruh dalam membentuk karakter manusia-manusia yang 'berwatak' khas, seperti: populis, nerimo ananing pandum, suka berderma, ikhlas serta karakterkaraktr yang lain yang amat jarang ditemukan dalam masyarakat modern saat ini. Karena dasar tujuan didirikanya pesantren adalah menciptakan dan mengembangkan kepribadian muslim, yakni kepribadian yang beriman dan bertaqwa kepada Allah SWT, berakhlak mulia dan bermanfaat bagi masyarakat sekitar, maka wajar kalau seseorang yang belajar di pesantren disebut dengan istilah santri. Istilah ini menurut Manfred Ziemek (1986:95), terdiri dari kata 'sant' (manusia baik) dihubungkan dengan suatu kata 'tri' (suka menolong). Jadi pesantren berarti tempat pendidikan manusia baik-baik. Sebetulnya tidak ada tujuan pendidikan pesantren yang secara eksplisit tertera dalam anggaran dasar seperti yang terjadi pada pendidikan formal. Hal ini diakibatkan oleh sifat kesederhanaan pesantren yang sesuai dengan dasar berdirinya yaitu semata- 
mata untuk beribadah dan tidak pernah ditujukan dengan tujuan tertentu dalam lapangan penghidupan. Tujuan pesantren tidak semata-mata untuk memperkaya pikiran murid dengan penjelasan-penjelasan, tetapi untuk meningkatkan moral, melatih dan mempertinggi semangat, menghargai nilai-nilai spiritual dan kemanusiaan, mengajarkan sikap dan tingkah laku yang jujur dan bermoral dan menyiapkan murid untuk hidup sederhana dan bersih hati.

Penelitian ini mengkaji pola komunikasi antara kyai dengan santri di pesantren Raudhatul Qur'an AnNasimiyyah Semarang. Pola Komunikasi yang dimaksud dalam penelitian yakni pola komunikasi seorang kyai sebagai pemimpin pondok pesantren dengan para santrinya. Sehingga dalam penelitian ini pesantren yang dimaksud diposisikan sebagai sebuah organisasi yang dijadikan sebagai sasaran dalam penelitian. Signifikansi penelitian ini terletak pada pengetahuan mengenai pola komunikasi yang dianggap penting khususnya pola komunikasi seorang atasan dengan bawahan, yang nantinya dari pola komunikasi tersebut dapat diprediksi proses komunikasi yang sedang atau akan berlangsung, sehingga proses komunikasinya dapat berjalan dengan seimbang (Sri, 2014:630).

Pesantren adalah sebuah kehidupan yang unik, sebagaimana dapat disimpulkan dari gambaran lahiriahnya. Secara fisik, pesantren adalah sebuah kompleks yang umumnya berbeda dari kehidupan sekitarnya. Dalam kompleks itu terdiri atas beberapa bangunan yaitu: rumah kediaman pengasuh (kyai), sebuah aula atau masjid, tempat pengajaran diberikan, dan asrama tempat tinggal para siswa pesantren/santri. Wahjoetomo menyatakan hal yang serupa bahwa komplek pesantren minimal terdiri atas rumah kediaman kyai, masjid atau musholla, dan asrama santri. Tidak ada model atau patokan tertentu dalam pembangunan fisik pesantren, sehingga penambahan bangunan dalam lingkungan pesantren hanya mengambil bentuk improvisasi belaka (Loubna dan Faturochman, 2004:33).

Penelitian ini menjadi menarik sebab beberapa alasan, pesantren adalah lembaga pendidikan yang dikembangkan dengan menejemen yang unik, yaitu penerapan nilai-nilai agama yang dijadikan basis pengembangan organisasi di setiap perubahan zaman (Kementrian Agama RI, 2012). Pesantren Raudhatul Qur'an An-Nasimiyyah adalah pesantren dengan sistem pengajaran salafiyah yang diapdankan dengan fasilitas yang cukup modernis. Disamping itu, Pesantren Raudhatul Qur'an ini dikenal sebagai pesantren yang unik karena para santrinya berasal dari berbagai lembaga pendidikan dari mulai pendidikan dasar sampai dengan mahasiswa pascasarjana dan berasal dari beragam kampus dan berbagai jurusan/konsentrasi di Kota Semarang, Jawa Tengah, dan bahkan ada yang juga kuliah diluar kota. Maka tidak mengherankan apabila pesantren Raudhatul Qur'an An-Nasimiyyah ini menjadi role-model pesantren mahasiswa yang ada di Indonesia.

Secara teoretis penelitian dalam bidang ini penting dilakukan guna mengangkat pengetahuan model komunikasi timur menjadi ilmu pengetahuan. Bahwa masyarakat Asia memiliki khazanah kajian ilmu pengetahuan komunikasi yang khas, yang amat penting untuk dipahami dan dikembangkan lebih lanjut. Secara empiris penelitian ini penting dilakukan guna mereduksi stigma negatif santri di pesantren yang mana selama ini sering terlihat eksklusif dan jarang membaur dengan masyarakat setempat. Mengetahui salah satu model komunikasi yang terdapat di Pesantren terutama Pesantren Raudhatul Qur'an 
An-Nasimiyyah antara kyai dengan santrinya diharapkan dapat memberikan perspektif baru kepada masyarakat awam dan para santri tentang bagaimana berkomunikasi secara Islami. Tujuan dari pada penelitian ini adalah dalam rangka menyusun, memahami dan menganalisis model komunikasi antara kyai dengan santri, khususnya di pesantren Raudhatul Qur'an An-Nasimiyyah Semarang.

Dari ragam penjelasan teori diatas kiranya terdapat relevansi yang penting untuk menjelaskan pembahasan dalam kaitannya tentang pola komunikasi kyai dengan santrinya di sebuah pesantren. Dalam kaitannya dengan hal ini penulis mengambil teorinya McLuhan tentang komunikasi antar budaya.

\section{Metode Penelitian}

Terdapat dua pendekatan utama yang kedudukannya sejajar dalam memandang manusia (pasif-aktif), yaitu pendekatan objektif (behavioristik dan struktural) dan pendekatan subjektif (fenomenologis atau interpretif). Pada pendekatan objektif, dunia sosial dianggap mirip dengan dunia fisik, sebagai sesuatu yang konkret dan terpisah dari orang yang mengamatinya, dengan suatu struktur yang harus dan dapat ditemukan. Sementara itu, pendekatan subjektif (fenomenologis) meyakini realitas sosial sebagai kondisi yang cair dan mudah berubah melalui interaksi manusia dalam kehidupan sehari-hari. Pendekatan ini diarahkan untuk memahami perilaku manusia dari kerangka berpikir pelaku itu sendiri (Fuad, 2013:200).

Penelitian ini menggunakan metode kualitatif studi fenomenologi. Pendekatan kualitatif adalah suatu proses penelitian dan pemahaman yang berdasarkan pada metodologi yang menyelidiki suatu fenomena sosial dan masalah manusia. Metode ini digunakan karena mampu menjelaskan hubungan antar kategori yang nantinya ditemukan dan disusun dalam penelitian ini. Metode kualitatif juga mampu menggambarkan dan menganalisis pola perilaku manusia.

Metode yang dilakukan dalam penelitian ini adalah studi fenomenologi. Fenomenologi berusaha untuk memahami bagaimana seseorang mengalami dan memberi makna pada sebuah pengalaman. Fenomenologi berusaha mendekati objek kajian secara konstruktivis serta pengamatan yang cermat, dengan tidak menyertakan prasangka oleh konsepsi-konsepsi manapun sebelumnya. Fenomenologi akan berusaha memahami pemahamaninforman terhadap fenomena yang muncul dalam kesadarannya, serta fenomena yang dialami oleh informan dan dianggap sebagai entitis sesuatu yang ada dalam dunia. Metode ini digunakan karena struktur kesadaran dalam pengalaman ini pada akhirnya membuat makna dan menentukan isi dari pengalaman.

Penelitian ini dilakukan untuk memberikan gambaran secara lebih mendalam mengenai bentuk komunikasi dari kyai, dimana mereka merupakan orangorang yang tumbuh, berkembang dan belajar dalam frame pendidikan Islam, dimana Al-Quran sebagai sumber utama keilmuan mereka. Perilaku mereka sehari-hari akan dinilai untuk kemudian disusun dan sebagai model komunikasi antara kyai dengan santrinya. Sehingga, secara spesifik metode yang digunakan dalam penelitian ini adalah fenomenologi sosial Schutz. Mengacu pada pendapat Cresswel, fenomenologi sosial berfokus pada bagaimana anggota masyarakat menggambarkan dunia keseharian, khususnya bagaimana individu secara sadar mengembangkan makna dari hasil interaksinya dengan orang lain.

\section{Metode Pengumpulan Data}

Terdapat empat tipe utama data, meliputi data observasi, data interview, dokumen dan data audio-visual. Dalam penelitian ini, data yang digunakan berupa hasil wawancara (data interview), 
sehingga teknik pengumpulan data dilaksanakan melalui wawancara mendalam (depth interview) dan observasi partisipan kepada informan, hal ini dilakukan karena melalui metode inilah didapatkan esensi fenomena dari sudut pandang orang yang mengalaminya secara langsung. Hal ini dilakukan untuk meminimalisir distorsi data yang dapat menghilangkan esensi dari penelitian. Observasi partisipan merupakan teknik berpartisipasi yang sifatnya interaktif dalam situasi yang alamiah dan melalui penggunaan waktu serta catatan observasi untuk menjelaskan apa yang terjadi. Observasi partisipan pada dasarnya berarti mengadakan pengamatan dan mendengarkan dengan secermat mungkin sampai pada yang sekecil-kecilnya sekalipun. Bogdan juga melengkapi bahwa observasi partisipan adalah penelitian yang bercirikan interaksi sosial yang memakan waktu cukup lama antara peneliti dengan subjek dalam lingkungan subjek, dan selama itu data dalam bentuk catatan lapangan dikumpulkan secara sistematis dan berjalan tanpa gangguan.

Dalam observasi partisipan, ada banyak kategori peran partisipan yang terjadi dilapangan penelitian kualitatif, yaitu ; (a)Peran serta lengkap. Pengamat dalam hal ini menjadi anggota penuh dari kelompok teramati. Ia akan memperoleh informasi apapun yang dibutuhkan, termasuk yang dirahasiakan, (b) Peran serta sebagai pengamat. Peneliti berperan sebagai pengamat (fly on the wall). Kalaupun ia menjadi anggota, ia hanya berpura-pura saja, tidak melebur secara fisik maupun psikis dalam arti yang sesungguhnya, (c) Pengamat sebagai pemeran serta. Pengamat yang secara terbuka oleh umum disponsori oleh subjek. Karena itu segala macam informasi akan mudah diperolehnya, (d) Pengamat penuh. Kondisi ini biasanya kedudukan antara pengamat dengan teramati dipisah oleh satu dinding pemisah yang hanya meneruskan informasi satu arah saja. Subjek tidak merasa sedang diamati.

Penelitian ini menggunakan sistem peran serta lengkap, dimana peneliti menjadi pengamat dalam hal ini menjadi anggota penuh dari kelompok teramati selama lebih kurang 3 tahun dimulai sejak 3 Juli2013 sampai dengan saatini (27Maret 2016) penulis masih rutin berkunjung ke tempat penelitian, baik kapasitasnya sebagai anggota maupun sebagai peneliti. Sehingga dapat memperoleh informasi apapun yang dibutuhkan, termasuk yang dirahasiakan.

Kriteria informan dalam penelitian fenomenologi adalah orang-orang yang mengalami langsung suatu fenomena yang hendak diteliti dan dapat mengartikulasikan pengalaman-pengalaman sadarnya. Cresswell berpendapat hal terpenting di dalam penelitian fenomenologi adalah mendeskripsikan makna atas sejumlah kecil orang yang mengalami suatu fenomena. Sehingga berapapun jumlah informan bukan menjadi ukuran, selama sudah mampu memberikan informasi yang cukup. Dalam kaitannya dengan penelitian ini penulis mewawancara 4 Kyai, yakni utamanya kyai dari pesantren tempat penelitian dengan ditambah kyai dari 3 pondok pesantren. Informan yang membantu dalam menggali model komunikasi interpersonal ini adalah kyai yang dipilih melalui beberapa kriteria. Kriteria informan dalam penelitian ini antara lain ; (a) Merupakan seorang pendakwah, (b) Pernah dan atau aktif sebagai pengurus lembaga dan atau organisasi Islam, (c) Pernah mengenyam dan menyelesaikan pendidikan sebagai santri di Pesantren, (d) Pernah mengenyam dan menyelesaikan pendidikan tinggi baik keilmuan umum maupun keagamaan.

Sedangkan informan dengan santri berjumlah 8 orang yang terlibat aktif sebagai pengurus maupun sebagai santri pondok pesantren. 


\section{Metode Analisis Data}

Analisis data adalah analisis terhadap data yang telah tersusun atau data yang telah diperoleh dari hasil penelitian di lapangan. Dalam hal ini penulis menggunakan metode data kualitatif yaitu proses pelacakan dan pengaturan secara sistematis, transkip, wawancara, catatan lapangan, dan bahan-bahan lain yang dikumpulkan untuk menemukan makna terhadap data-data tersebut agar dapat diinterpretasikan temuannya pada orang lain (Nurul, 2006:217).

Analisis data pada penelitian kualitatif ini bersifat induktif, yaitu suatu analisis berdasarkan data yang diperoleh. Selanjutnya dikembangkan pola hubungan tertentu kemudian disimpulkan sehingga menjadi data yang valid, mudah difahami oleh diri sendiri maupun orang lain.

Penulis menggunakan analisis data di lapangan dengan model Miles dan Huberman, yaitu pengumpulan data dilakukan secara berulang-ulang sampai tuntas dan data dianggap kredibel (Sugiyono, 2009:9). Adapun langkah-langkah proses analisis data dalam penelitian ini adalah sebagai berikut; (a)Data reduction (reduksi data). Mereduksi data berarti merangkum, memilih hal-hal yang pokok, memfokuskan hal-hal yang penting, dicari tema dan polanya dan membuang yang tidak perlu. Dengan demikian data yang telah direduksikan memberikan data yang lebih jelas dan mempermudah penulis untuk melakukan pengumpulan data mengenai pola komunikasi kyai dengan santri di pesantren Raudhatul Qur'an An-Nasimiyyah Semarang yang dikumpulkan dengan wawancara, observasi, dan dokumentasi untuk kemudian dijadikan rangkuman, (b) Data display (penyajian data). Penyajian data adalah suatu cara merangkai data dalam suatu organisasi yang memudahkan untuk membuat kesimpulan/tindakan yang diusulkan (Ali, 1993:167). Setelah data direduksi maka langkah selanjutnya adalah mendisplaykan atau menyajikan data. Tujuannya adalah untuk menyederhanakan informasi, dari informasi yang kompleks ke informasi yang sederhana sehingga mudah dipahami maksudnya, (c) Conclusion drawing/verification (penarikan kesimpulan). Langkah ketiga dalam analisis data kualitatif menurut Miles dan Huberman adalah penarikan kesimpulan dan verifikasi (Sugiyono, 2009:15). Penulis dalam melakukan penarikan kesimpulan dengan mencermati dan menggunakan pola pikir yang dikembangkan. Penarikan kesimpulan dari hasil penelitian ini menjawab semua rumusan masalah yang telah ditetapkan oleh peneliti.

Dengan demikian kesimpulan dalam penelitian kualitatif mungkin dapat menjawab rumusan masalah yang dirumuskan sejak awal, tetapi mungkin juga tidak, karena seperti telah dikemukakan bahwa masalah dan rumusan masalah dalam penelitian kualitatif masih bersifat sementara dan akan berkembang setelah peneliti berada di lapangan.

Ringkasnya, dalam analisis data ini peneliti menggunakan analisis deskriptif yaitu penelitian yang digunakan untuk mendeskripsikan dan menginterpretasikan hasil penelitian tentang bagaimana model komunikasi kyai dengan santri di pesantren Raudhatul Qur'an An-Nasimiyyah Semarang.

\section{Hasil Penelitian dan Pembahasan}

Model komunikasi kyai dengan santri yang ada di Pesantren Raudhatul Qur'an An-Nasimiyyah Semarang ini yang menjadi fokus penelitiannya model komunikasi organisasi, dimana dalam komunikasi organisasi terdapat teori budaya organisasi sebagaimana yang dijelaskan oleh Littlejohn dan Karen A. Foss (2012:282) yakni teori-teori tentang 
budaya organisasi menekankan pada cara-cara manusia membentuk realitas organisasi. Sebagai penelitian tentang cara hidup organisasi, pendekatan ini melihat pada makna dan nilai anggota. Pendekatan ini menguji cara individu menggunakan cerita, ritual, simbol, dan kegiatan lain untuk menghasilkan kembali pemahaman (restrukturisasi).

Kyai merupakan titik puncak daripada sebuah organisasi di pesantren. Dimana peran kyai sangat berpengaruh terhadap eksistensi daripada sebuah pesantren. Dikarenakan pola komunikasi seorang kyai tidak dapat sepenuhnya dijelaskan dengan teori komunikasi barat yang ada sebelumunya.

Pada kasus pondok pesantren Raudhatul Qur'an An-Nasimiyyah, apabila merujuk pada pembagian santri, maka santri di pondok pesantren saat dilakukan penelitian adalah terdapat santri mukim dan santri kalong.

Banyaknya santri mukim disebabkan kriteria santri yang ada rata-rata berasal dari luar kota maupun daerah, mereka tinggal di pesantren sambil kuliah pada siang harinya dan kembali ke pesantren untuk mengikuti kegiatan pesantren sebelum magrib.

Secara umum, dalam berbagai hal, pendekatan struktural dan fungsional mengenai organisasi hanya menekankan pada produktifitas dan penyelesaian tugas-tugas pekerjaan, sedangkan faktor manusia dipandang sebagai variabel dalam suatu pengertian yang lebih luas. Oleh karena itu Agrys (Burhan, 2014:280) mencoba menjelaskan pandangannya melalui pendekatan human relations untuk mengkritik perspektif struktural fungsional. Ada beberapa anggapan dasar dari pendekatan human relations, yaitu ; (a) Produktifitas ditentukan oleh norma sosial, bukan faktor psikologis, (b) Seluruh imbalan yang bersifat non ekonomis, sangat penting dalam memotivasi para santri, (c) santri biasanya memberikan reaksi suatu persoalan, lebih sebagai anggota kelompok daripada individu, (d) Kepemimpinan memegang peranan yang sangat penting dan mencakup aspekaspek formal dan informal, (e) Penganut aliran human relations menganggap komunikasi sebagai fasilitator penting dalam proses pembuatan keputusan.

Santri, dalam hal ini merupakan komponen sasaran komunikasi dalam model komunikasi kyai dan santri, yang merupakan audience utama dalam konteks komunikasi pengajaran di Pesantren Raudhatul Qur'an An-Nasimiyyah. Usahausaha yang dilakukan oleh kyai pada dasarnya adalah untuk dapat menyampaikan pesan secara efektif kepada santri. Keberadaan dan kualitas santri merupakan ajang pembuktian dan pengukuhan kualitas kyai ditilik dari sudut pandang sosial.

Beberapa hal yang peneliti tanyakan dan peneliti amati dalam keseharian santri-santri menujukkan bahwa terdapat beberapa faktor yang menjadikan seorang santri taat kepada seorang kyai, antara lain yakni ; (1)Adanya kharisma yang tidak dapat dijelaskan oleh santri mengapa mereka taat kepada kyai, (2) Adanya faktor bawaan dari santri yang sebelumnya terbentuk dari kultur budaya pesantren yang menjunjung tinggi akhlak seorang murid kepada gurunya, (3) Adanya keluasan ilmu yang dimiliki oleh Kyai, terutama ilmu tentang keislaman, (4)Adanya sikap kebapakan yang dimiliki oleh Kyai sehingga santri-santri di pesantren merasa nyaman dan hormat, (5)Luhurnya akhlak Kyai sehingga dapat dijadikan role-model bagi santri-santrinya.

Berdasarkan penjelasan diatas, maka model komunikasi antara kyai dengan santri dapat digambar dalam model diagram sebagai berikut:

Bagan 1. menjelaskan; (1) Kedudukan seorang kyai adalah sebagai sender (komunikator) yang dapat membentuk 


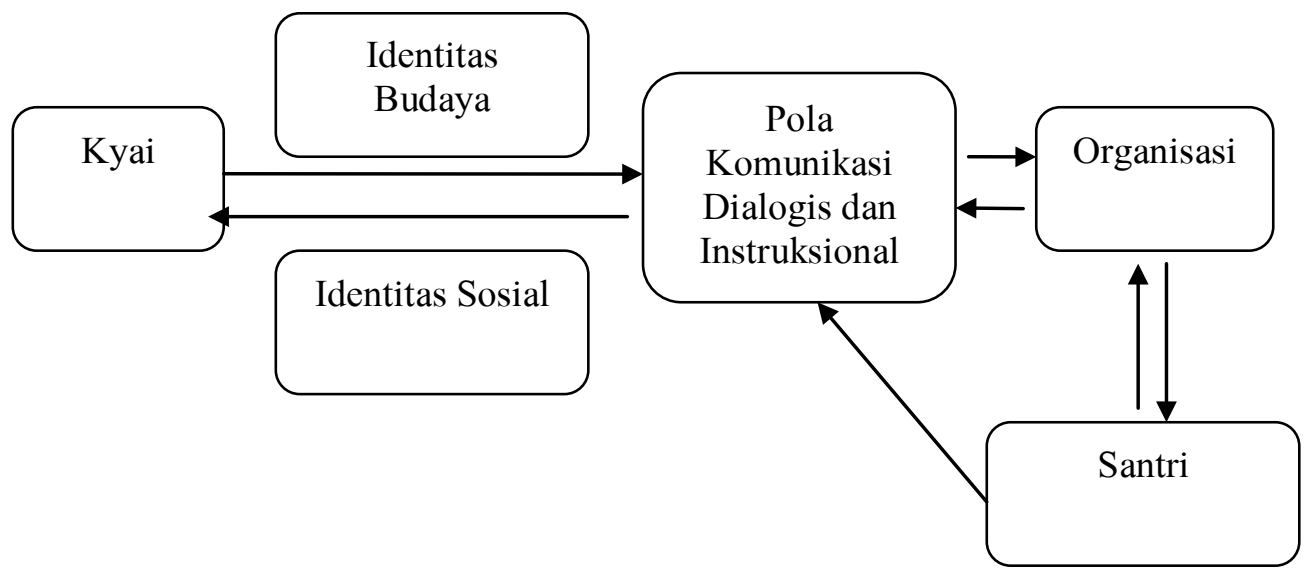

Gambar 1. Model Komunikasi Antara Kyai dan Santri

pola komunikasi dibawahnya, (2)Dalam konteks komunikasi, kyai dipengaruhi kuat oleh identitas budaya dan status sosial di masyarakat, dengan ini kedudukan kyai adalah sebagai role-model bagi receiver (pengurus dan santri), (3)Pola komunikasi berlangsung dialogis dan instruksional terbatas dengan pola-pola dan sikap tertentu, (4)Organisasi dibawah kyai adalah organisasi yang berfungsi sebagai media maupun kepanjangan tangan dari kyai kepada santrinya, (5) Santri sebagai receiver (penerima pesan), dan dalam berkomunikasi ke atas (sender) bersifat terbatas dalam persoalan tertentu.

\section{Simpulan}

Berdasarkan penelitian yang telah dilakukan di Pesantren Raudhatul Qur'an An-nasimiyyah, Kelurahan Bojong Salaman, Kecamatan Semarang Barat, Kota Semarang mengenai Model Komunikasi Kyai dan Santri di Pesantren, maka dapat ditarik kesimpulan bahwa:

Konstruksi model Komunikasi Kyai dengan Santri di Pesantren Raudhatul Qur'an An-nasimiyyah terbentuk dari intensitas interaksi yang tinggi antara Kyai dengan Santri lewat suatu organisasi maupun secara langsung. Sifat komunikasi dari kyai ke bawah adalah mutlak, sedangkan model komunikasi santri (receiver) kepada kyai (sender) adalah terbatas dalam lingkup persoalan tertentu. Dalam komunikasi model demikian maka diharapkan akan lahir keseganan dari santri kepada kyai. Selajutnya dalam proses transfer of knowledge menjadi lebih mudah. Pola komunikasi seperti ini dipandang cukup ideal dalam pendidikan akhlak.

\section{Daftar Pustaka}

Ali, Mohammad. (1993). Strategi Penelitian Pendidikan, Bandung: Angkasa.

Bungin, Burhan. (2014) Sosiologi Komunikasi. Jakarta: Kencana.

Fiske, John. (2004). Pengantar Ilmu Кomunikasi. Jakarta: PT Rajagrafindo Persada.

Ikhwanudin, Alim. 2010. "Perilaku Kesehatan Santri". Jurnal Sosial dan Politik. Fakultas Ilmu Sosial dan Ilmu Politik Universitas Airlangga.

Izzah, Iva Yulianti Umdatul Izzah. (2011). "Perubahan Pola Hubungan Kyai dan Santri pada Masyarakat MuslimTradisonal Pedesaan". Jurnal Sosiologi Islam. 1 (2), 31-48.

Kementrian Agama RI. (2012). Buku Panduan Integrasi Kultur Pesantren Ke Dalam Menejemen Sekolah. Jakarta:. Kemenag RI.

Littejohn, Stephen W., Karen Foss. (2012). Teori Komunikasi. Jakarta: Salemba Humanika. 
Loubna Zakiah \& Faturochman. (2004). "Kepercayaan Santri Kepada Kyai". Buletin Psikologi. 12 (1), 33-43.

Ma'arif, Syamsul. (2010). “Pola Hubungan Patron-Client Kyai dan Santri di Pesantren". Jurnal Ta'dib. 15 (2), 273-296.

Mulyana, D. (2004). Ilmu Komunikasi Suatu Pengantar. Bandung: PT. Remaja Rosdakarya.

Nasvian, Moh. Fuad. (2013). “Model Komunikasi Kyai dengan Santri". Jurnal Wacana. 16 (4), 197-206.

Rizki Respati Suci. 2010. “Strategi Pemberdayaan Santri di Pondok Pesantren
Hidayatullah Donoharjo Ngaglik Sleman Yogyakarta". Skripsi. Yogyakarta: Fakultas Dakwah UIN Sunan Kalijaga.

Sugiyono. (2009). Metode Penelitian Kuantitatif, Kualitatif RED, Bandung: Alfabeta.

Wulandari, Sri. (2014). "Pola Komunikasi Kyai di Pondok Pesantren". Jurnal Commonline Departemen Komunikasi. 3 (3), 630-644.

Zuriah, Nurul. 2006. Metodologi Penelitian Sosial dan Pendidikan Teori- Aplikasi, Jakarta: PT Bumi Aksara. 